\title{
The Production, Preservation and Dissemination of Archaeological Data in Japan
}

Yuichi Takata and Peter Yanase

\section{Summary}

Japan is producing a vast amount of archaeological data because of the high number of rescue excavations taking place every year in the country. However, municipal administrations are struggling to cope with storing and disseminating the accumulated data. This article gives an overview of how fieldwork reports and archaeological illustrations are framed in national policies and how that affects the way they are handled locally, both in physical and digital form.

\section{Introduction}

Japan may be the biggest producer of archaeological data in the world. According to our estimate, the number of fieldwork reports published in Japan is around 125,000, which roughly equals 15.57 million pages with 9.7 billion characters and 9.5 million images (Takata 2019). The original drawings, photographs, charts, and graphs produced during or after the excavations amount to 104.37 million pieces, according to the most recent estimate (Maizō bunkazai hakkutsu chōsa taisei tō no seibi jūjitsu ni kansuru chōsa kenkyū iinkai 2003).

In this article, we briefly describe why such an enormous amount of data was accumulated, how it is stored and disseminated, who funds its production and storage and, finally, current efforts to further the (re)usability of Japanese archaeological data in the digital age.

The reader might find some of the translations of laws and policies presented here sound somewhat unnatural. This is intentional, to show the carefully chosen language of the texts. 


\section{The Rapid Accumulation of Data}

Most Japanese archaeological data is derived from rescue excavations undertaken prior to development projects for highways, railways, or housing areas. The number of annual rescue excavations over the last twenty years has fluctuated between 7-9000. During the same period, the number of purely academic excavations only rose above an annual five hundred once, in 2002. Rescue excavations not only outnumber academic excavations, but they produce archaeological data based on entirely different criteria.

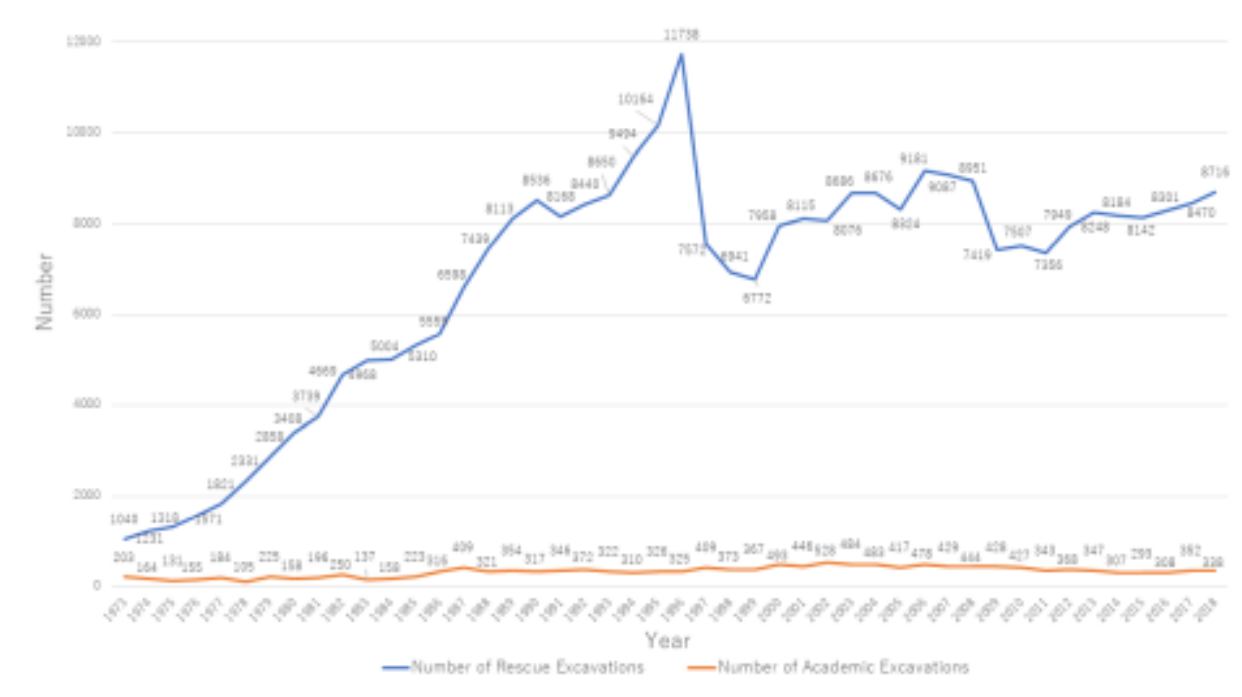

Figure 1: The number of annual excavations between 1973 and 2018 (data from Second Cultural Properties Division, Agency for Cultural Affairs 2020)

The details of governmental policy defining the requirements for rescue excavations can be found in the Law for the Protection of Cultural Properties (enacted in 1950, last amended in 2020). The most relevant articles are nos 93-95. Article 95 states that local governments 'must make efforts' to disseminate information about 'well-known buriedcultural-property-containing subsoil' (such as shell or burial mounds). Articles 93 and 94 state that if a developer wishes to dig into the ground on such land, they must notify the authorities about their plans. Article 93 further states that 'when it is recognised that it is particularly necessary for the protection of buried cultural properties', the authorities may instruct that an archaeological excavation should take place prior to the development work in order 'to make a record of the buried cultural properties'. The vaguely-worded law effectively states that local governments need to register archaeologically relevant sites, and said sites should be preserved as a general rule. However, a registered site can be destroyed or altered if unavoidable. In this case, the authorities may request a thorough pre-construction excavation that retrieves all relevant artefacts and data from the site first. The resulting data must act as a form of replacement for the perished portions of the site.

This law is needed because there are roughly 460,000 registered archaeological sites in Japan (Second Cultural Properties Division, Agency for Cultural Affairs 2020), a country with a total landmass of $c$. 378,000 square kilometres, two-thirds of which is either covered with forest or mountains. This means all past or present settlements were primarily built on the remaining flatland and coastal areas, resulting in an extremely high 
density of roughly 3.6 registered sites per populated square kilometre. In turn, this means that to build anything at all, registered sites must be disturbed. The law makes sure that if a registered site cannot be preserved in its original state, at least the information contained within the soil is collected beforehand.

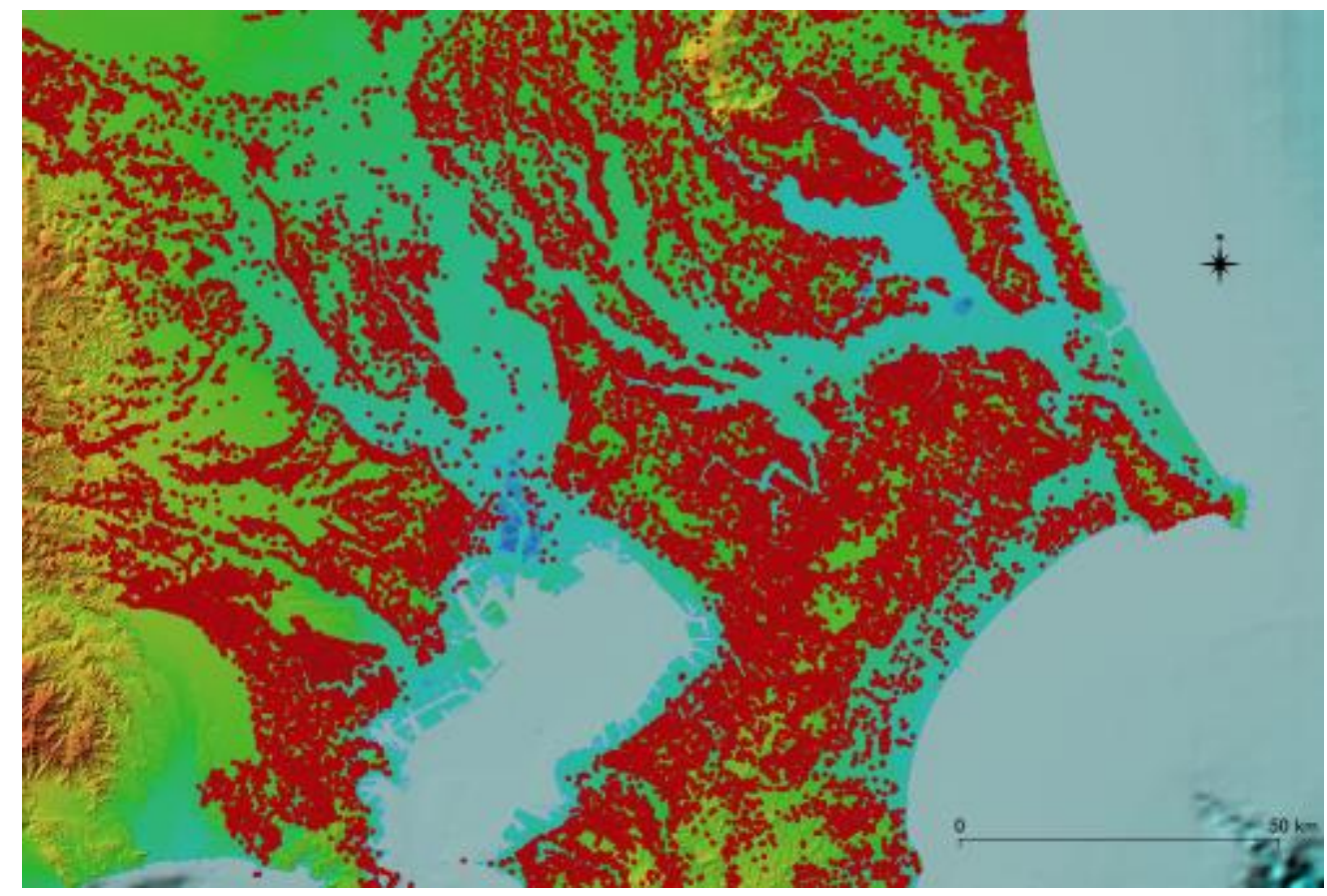

Figure 2: The density of registered archaeological sites in Tokyo

To sum up, the high number of registered archaeological sites leads to a high number of rescue excavations. And because the data produced at the excavations are framed as replacement for the destroyed portion of these sites, the archaeological data are extremely detailed. These two factors combined lead to the rapid and constant accumulation of archaeological data in Japan.

\section{The Storage of Physical Data}

Two types of physical data emerge from rescue excavations: primary archaeological data, such as scale drawings, charts, maps, and photographs, and secondary data, the fieldwork report. Although no legislation explicitly states so, fieldwork reports are considered to be end-products of excavations and the culmination of the retrieved data. As a proposal from the Science Council of Japan states: '[Fieldwork reports] are the most central ( $\mathrm{sic}$ ) among the records left for future generations as replacements for buried cultural properties that could not be preserved in their original form, and they [are the ones that] make it possible to disseminate and utilise the results of excavations.' (Bunkazai no hogo to katsuyō ni kan suru bunkakai 2017). The Agency for Cultural Affairs states similarly, that 'Because fieldwork reports are such records of buried cultural properties that accurately summarise the results of excavations, it is necessary to take measures to preserve them for the future and make them public so that they could be shared and utilised by the people' (Monuments and Sites Division, Agency for Cultural Affairs \& Nara National Research Institute for Cultural Properties 2010). In other words, both the primary data and the fieldwork reports are framed as replacements for the disturbed portions of the sites that should be preserved with utmost care. 
Although no data are available about the storage practices concerning fieldwork reports, it is fair to assume that most of them are stored in libraries, reading rooms, or at the very least on bookshelves. On the other hand, the previously mentioned 2003 survey on the archaeological data storage practices of local governments paints a gloomy picture of the state of primary data: only $7 \%$ of the drawings and $8 \%$ of the photographs were stored in dedicated storehouses; a mere $19 \%$ of the photographs were stored in an environment with proper ventilation and humidity control; and a slim $8 \%$ of the visual data had back-up copies made (Maizō bunkazai hakkutsu chōsa taisei tō no seibi jūjitsu ni kansuru chōsa kenkyū iinkai 2003). In other words, greater care seems to be exercised in the storage of secondary data than primary data.

\section{Policies Regarding Physical Data}

The Agency for Cultural Affairs is actively debating the problem of data preservation. In 1994, the Agency set up a Committee 'to survey and research' the various problems surrounding (rescue) excavations (literally translated: Survey and Research Committee on the Improvement and Enrichment of the Excavation System of Buried Cultural Properties, etc.). This Committee is sporadically releasing nonbinding guidance in the form of reports. These - along with other seemingly random notices and memoranda released by various public entities - provide the basis for the (negotiable) rules of archaeological matters.

In the 2003 report, the Committee states that it is 'desirable' that archaeological data are stored in secure and properly ventilated buildings with necessary fire and disaster prevention measures implemented; that an easily searchable database is built for the maintenance of data; that important photographs and drawings have back-ups made and are stored separately; and that digitally stored data, along with the machine storing it, periodically gets updated (Maizō bunkazai hakkutsu chōsa taisei tō no seibi jūjitsu ni kansuru chōsa kenkyū iinkai 2003).

The 2004 report states that to promote the utilisation of the information acquired at the excavations, fieldwork reports need to be printed out and distributed to the 'related' libraries, museums, universities, research institutes, and governmental offices especially entities located near the site; and those who receive a copy need to store them and make them publicly accessible. Furthermore, in order to be able to grasp the 'situation of the publishing, etc. of fieldwork reports' nationwide, the database of the Nara National Research Institute for Cultural Properties ('NABUNKEN' from here on) 'needs to be enhanced'. (Maizō bunkazai hakkutsu chōsa taisei tō no seibi jūjitsu ni kansuru chōsa kenkyū iinkai 2004).

\section{Who Pays for the Production and Storage of Data?}

Regarding the production of data, a 1998 notice released by the Agency states that because the disturbance of a registered site is the fault of the developer, they should bear the expenses of 'preserving the site in records'. The phrase used here is misleading, because even though it literally means 'preservation', the notice clearly states that the developer is only expected to cover the expenses of the excavation, the 
processing of the artefacts, and the production of the fieldwork report (Agency for Cultural Affairs 1998). The storage and actual preservation of both the artefacts and the archaeological data fall on the local government. Since 2015, the State provides a grantin-aid for the 'utilisation of regionally-characteristic cultural properties', which can be used, among others, for building or repurposing storehouses for archaeological data. However, this only covers up to $50 \%$ of the expenses.

\section{What About Digital Data?}

The Agency published its guidance regarding digital data in three volumes between 2017 and 2019 (Maizō bunkazai hakkutsu chōsa taisei tō no seibi jūjitsu ni kansuru chōsa kenkyū iinkai 2017-2019). Volume one is about digital photography and the problems of digitisation and born-digital data, volume two is about the digitisation of fieldwork reports, while volume three is mainly about the digitisation of primary sources.

The most important take-away from these reports is that digitised data can never act as a replacement for physical data when there is no long-term digital preservation strategy in place. Currently, digitised data is used either as a back-up of physical data or as a tool to disseminate information about the physical data. Born-digital data need to be printed out and stored on physical discs and copied to optical discs and attached to site reports. In Japan, the long-term preservation of born-digital data is a problem yet to be solved.

As of 2020, there are no repositories for digitised or born-digital primary archaeological data. Instead, the State is currently promoting the construction of individual databases. Right now, the biggest question surrounding digital data and digitised data is how to secure the necessary funding. Unlike physical data, which can be stored in a storehouse, digital data needs to be managed and updated, and that requires both trained professionals and infrastructure. While there is grant-in-aid funding that can be used to build a database, it does not cover the long-term management of data.

On the other hand, NABUNKEN manages a central repository, the Comprehensive Database of Archaeological Site Reports in Japan (CDASRJ), which can be used to publish PDF versions of fieldwork reports free of charge. While the uploaded PDF files are neither structured data, nor on a par in quality with hard copy or print-ready PDF files, the repository is very popular. This is because the repository makes information easily available to which it would otherwise be near-impossible to obtain access owing to the limited circulation of the hard-copy reports. Also, many useful functions are implemented as part of the CDASRJ interface, such as full-text search or advanced search based on meticulously built meta-data. For a detailed description of the history and functions of the repository see Takata et al. 2019. In addition, the Agency for Cultural Affairs is actively promoting the use of CDASRJ, contributing to its popularity. 


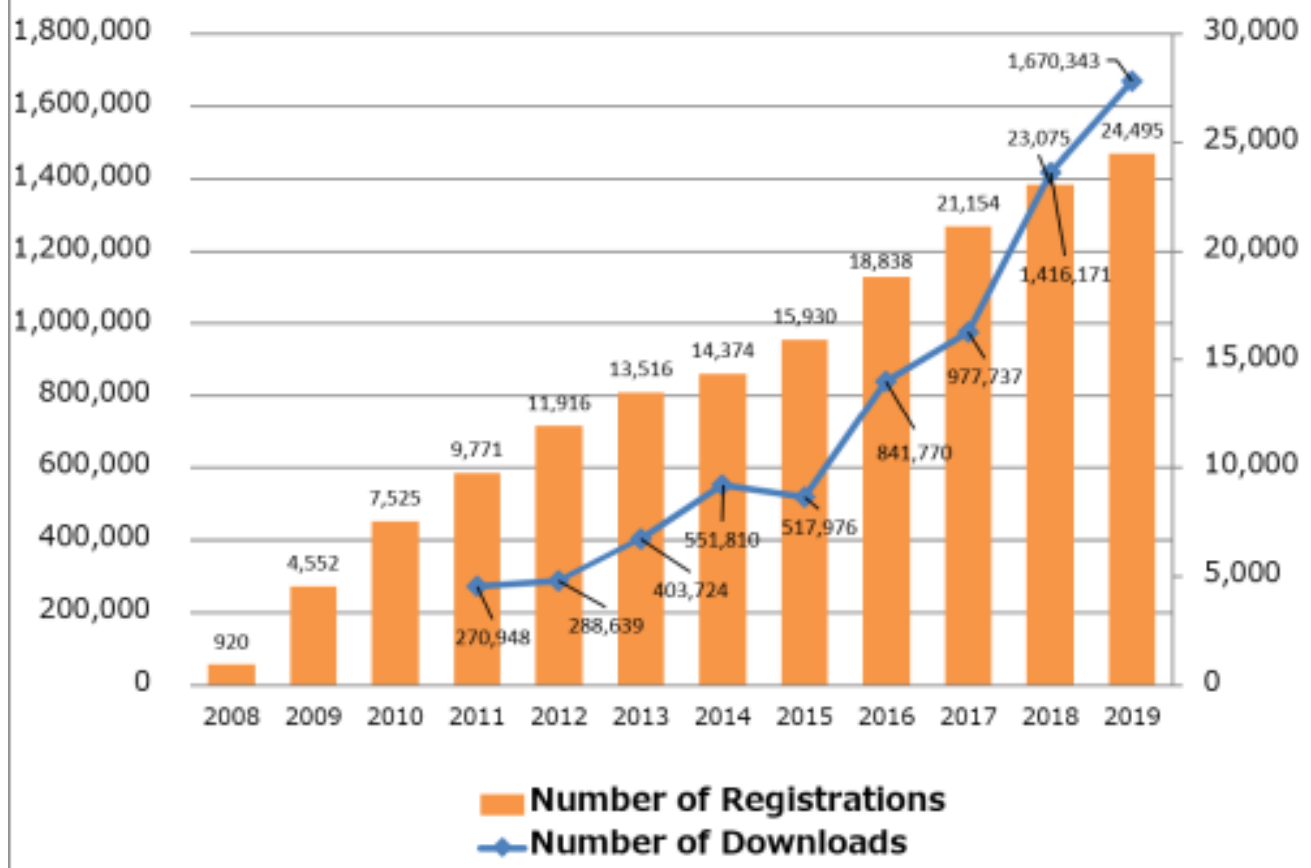

Figure 3: The number of registrations and downloads at CDASRJ between 2008 and 2019

\section{Conclusions}

In this article we have seen that, owing to the high number of rescue excavations, Japan is producing vast amounts of archaeological data on a yearly basis. However, the dissemination of data is, unfortunately, not of primary concern. Instead, archaeological data is meant to act as a replacement for the sites that are destroyed or altered by development projects. Because of this interpretation, the top priority will always be the preservation of physical data. In turn this means digital data is only used as a back-up of physical data or a way to disseminate information about physical data.

The biggest question surrounding digital data and digitised data is how to fund its longterm preservation. Digital data need to be managed in perpetuity, and that brings neverending attention and expense. However, there are no set rules or precedents about who should be responsible for the data in the long-term, and who should bear those expenses.

Broadly speaking, archaeological practice in Japan is based on governmental guidance, precedents, and mutual agreements between developers and local administration. This makes it difficult to bring new ideas into the current system, especially if they bring a financial burden to the entities involved. However, as the success of the CDASRJ shows, if there is a centrally managed repository and governmental guidance that promotes said repository, local administration will follow. 
Agency for Cultural Affairs 1998 Maizō bunkazai no hogo to hakkutsu chōsa no enkatsuka tō ni tsuite (tsūchi), Tokyo: Agency for Cultural Affairs.

Bunkazai no hogo to katsuyō ni kan suru bunkakai 2017 Teigen: Jizokuteki na bunkazai hogo no tame ni: toku ni maizō bunkazai ni okeru kikkin no kadai, Tokyo: Science Council of Japan. http://www.scj.go.jp/ja/info/kohyo/pdf/kohyo-23-t248-4.pdf [Last accessed: 25 January 2021].

Maizō bunkazai hakkutsu chōsa taisei tō no seibi jūjitsu ni kansuru chōsa kenkyū iinkai 2003 Shutsudohin no hokan ni tsuite (hōkoku), Tokyo: Agency for Cultural Affairs. http://doi.org/10.24484/sitereports.71606

Maizō bunkazai hakkutsu chōsa taisei tō no seibi jūjitsu ni kansuru chōsa kenkyū iinkai 2004 Gyōsei mokuteki de okonau maizō bunkazai no chōsa ni tsuite no hyōjun, Tokyo: Agency for Cultural Affairs. http://doi.org/10.24484/sitereports.71607

Maizō bunkazai hakkutsu chōsa taisei tō no seibi jūjitsu ni kansuru chōsa kenkyū iinkai 2017 Maizō bunkazai hogo gyōsei ni okeru dejitaru gijutsu no dōnyū ni tsuite 1 (hōkoku), Tokyo: Agency for Cultural Affairs. http://doi.org/10.24484/sitereports.71612

Maizō bunkazai hakkutsu chōsa taisei tō no seibi jūjitsu ni kansuru chōsa kenkyū iinkai 2017 Maizō bunkazai hogo gyōsei ni okeru dejitaru gijutsu no dōnyū ni tsuite 2 (hōkoku), Tokyo: Agency for Cultural Affairs. http://doi.org/10.24484/sitereports.71613

Maizō bunkazai hakkutsu chōsa taisei tō no seibi jūjitsu ni kansuru chōsa kenkyū iinkai 2019 Maizō bunkazai hogo gyōsei ni okeru dejitaru gijutsu no dōnyū ni tsuite 3 (hōkoku), Tokyo: Agency for Cultural Affairs. http://doi.org/10.24484/sitereports.71614

Monuments and Sites Division, Agency for Cultural Affairs \& Nara National Research Institute for Cultural Properties 2010 Hakkutsu chōsa no tebiki: Seiri, hōkokusho, Tokyo: Monuments and Sites Division, Agency for Cultural Affairs.

Second Cultural Properties Division, Agency for Cultural Affairs 2020 Maizō bunkazai kankei tōkei shiryō: Reiwa gannen do, Tokyo: Agency for Cultural Affairs. http://doi.org/10.24484/sitereports.71623

Takata Y. 2019 'Hakkutsuchōsa hōkokusho no dētaryō wo suikei suru', Bunkazai no tsubo 7, 4-5.

Takata Y., Kaneda A. and Dessislava V. 2019 'Prospects and potential for the comprehensive database of archaeological site reports in Japan' in F. Niccolucci and J. Richards (eds) The ARIADNE Impact, Hungary: Archaeolingua Foundation. 17585. http://doi.org/10.5281/zenodo.3476712 